The Free Internet Journal

for Organic Chemistry
Paper

Arkivoc 2018, part ii, 131-144

\title{
Tuning the coverage of self-assembled monolayer by introducing bulky substituents onto rigid adamantane tripod
}

\author{
Toshikazu Kitagawa, ${ }^{\text {a }}$ Shima Nakanishi, ${ }^{a}$ Aya Mizuno, ${ }^{a}$ Yohei Niwa, ${ }^{a}$ Hiroki Tabata, ${ }^{a}$ Katsuyuki Hirai, ${ }^{b}$ and \\ Takao Okazaki*a \\ ${ }^{a}$ Department of Chemistry for Materials, Graduate School of Engineering, Mie University, Tsu, Mie 514-8507, \\ Japan \\ ${ }^{b}$ Organization for the Promotion of Regional Innovation, Mie University, Tsu, Mie 514-8507, Japan \\ Email: kitagawa@chem.mie-u.ac.jp
}

Dedicated to Professor Kenneth K. Laali on the occasion of his $65^{\text {th }}$ birthday

Received 10-08-2017

Accepted $10-27-2017$

Published on line 11-12-2017

\section{Abstract}

An area-demanding tripodal trithiol containing six peripheral methyl groups was synthesized, and its selfassembled monolayer (SAM) was formed onto a $A u(111)$ surface, which was electrochemically characterized. The SAM showed a significant lowering of the surface coverage due to the bulkiness of the methyl groups, as demonstrated by the charge of reductive elimination. The experimentally determined surface density was aptly reproduced by density functional theory (DFT) calculations under periodic boundary conditions.
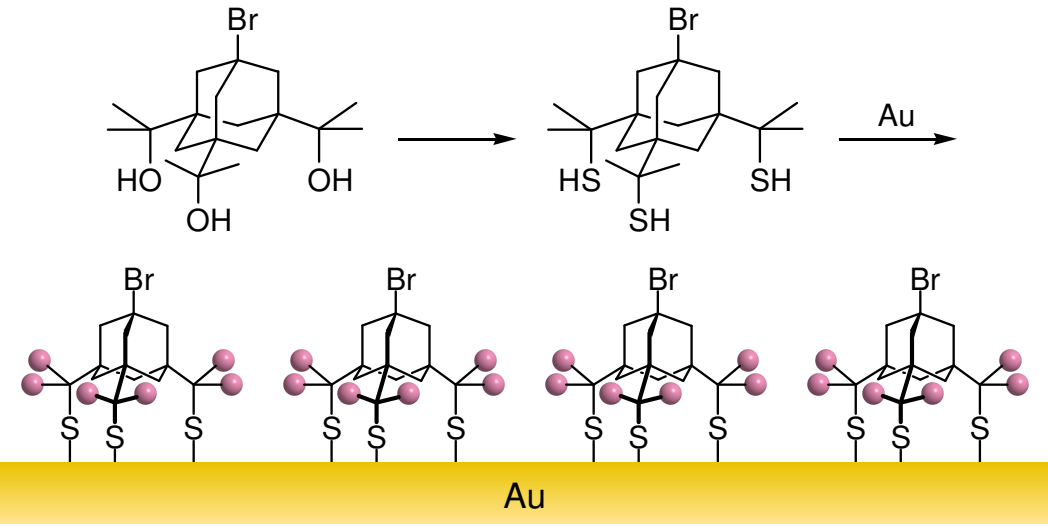

Keywords: Molecular tripod, self-assembled monolayer, adamantane, thiol, gold substrate 


\section{Introduction}

Thiols are readily chemisorbed on gold surface and form tight Au-S bond. Densely packed monolayers can be spontaneously constructed by simply immersing metallic gold into a thiol solution. ${ }^{1-3}$ Self-assembled monolayers (SAMs) prepared in this manner have attracted a great deal of attention for their utility in a variety of functional molecular assemblies that include molecular sensors, ${ }^{4,5}$ molecular machines, ${ }^{6,7}$ and molecular electronic devices. ${ }^{8,9}$ We previously reported that tripod-shaped trithiol 1, composed of a rigid adamantane core and three $\mathrm{CH}_{2} \mathrm{SH}$ legs, forms a SAM on $\mathrm{Au}(111)$ with a highly ordered arrangement by threepoint adsorption (Figure 1). ${ }^{10}$ Based on the results of scanning tunneling microscopy (STM) measurements, the SAM showed hexagonal $(3 \times 3) R 60^{\circ}$ packing with a closest molecular distance of $8.7 \AA$, which is a significantly larger distance than that normally observed for the SAMs of linear alkane thiols (5.0 $)$ ). Such a large distance allows SAMs of functional molecular units, connected at the top of the tripod, to be adsorbed without strong molecular interaction, which is sometimes unfavorable for the construction of functional SAMs. ${ }^{11,12}$

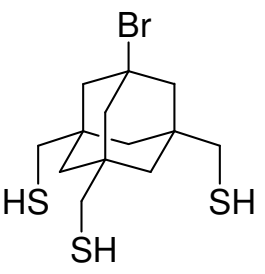

1

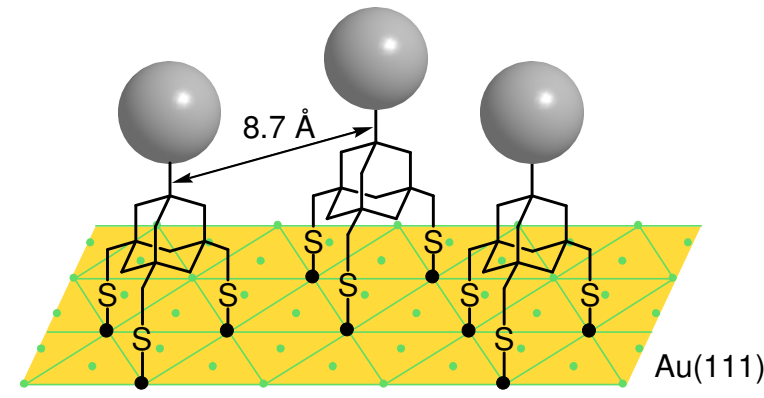

Figure 1. Tripodal trithiol with an adamantane core 1 and its SAM on a Au(111) surface. ${ }^{10}$ The gray spheres represent functional molecular unit.

In order to connect larger functional molecules, a more sterically demanding tripod is required to avoid molecular interactions within a SAM. In this paper, we report the synthesis of an adamantane tripod with three $\mathrm{CMe}_{2} \mathrm{SH}$ groups 2 (Figure 2). Due to the bulkiness of the protruding methyl groups, this molecule is expected to occupy a significantly larger surface area when adsorbed onto Au. The preparation of a SAM of 2 on $\mathrm{Au}(111)$ substrate is described, along with experimental and theoretical evaluations of the extended molecular distance.
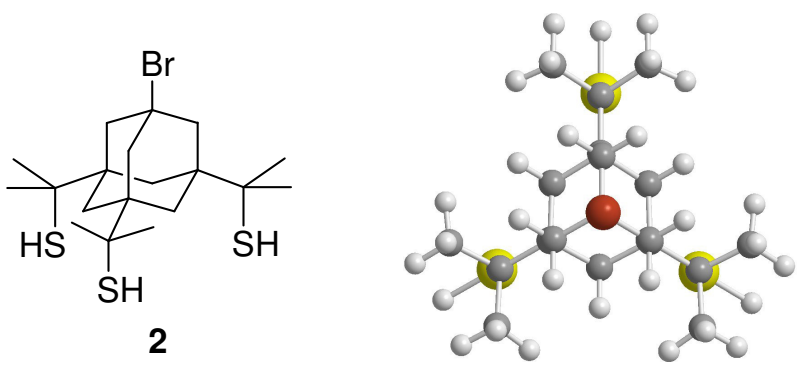

Figure 2. Sterically demanding hexamethylated molecular tripod 2. 


\section{Results and Discussion}

\section{Synthesis of a trithiol}

A common strategy for the synthesis of aliphatic thiols involves the conversion of the corresponding alcohols. Primary alcohols can be converted to thiol derivatives by converting the hydroxy group to a good leaving ester group, followed by a subsequent $\mathrm{S}_{\mathrm{N}}$ 2-type substitution using a sulfur nucleophile. ${ }^{10-12}$ The conversion into $\mathbf{2}$, with three tertiary thiol groups, however, requires substitution via a carbocationic intermediate under acidic conditions. In the present study, the starting alcohol is a hexamethyl triol 4. A good precursor of this triol is triester $\mathbf{3}$, which we synthesized earlier as a precursor of $\mathbf{1} .^{10}$

The synthesis of tertiary triol $\mathbf{4}$ via an exhaustive methylation of triester $\mathbf{3}$ requires multiple nucleophilic additions to the methoxycarbonyl groups bound to a bulky adamantyl group. The treatment of $\mathbf{3}$ with a large excess (12 eq.) of $\mathrm{MeMgl}$ at $0{ }^{\circ} \mathrm{C}$, however, gave 4 in only $20 \%$ yield along with a large amount of incompletely methylated products 5 and $\mathbf{6}$ (Scheme 1). Complete methylation was achieved at $50{ }^{\circ} \mathrm{C}$, but a concomitant loss of bromo group occurred at this temperature to give a considerable amount of unknown compounds.

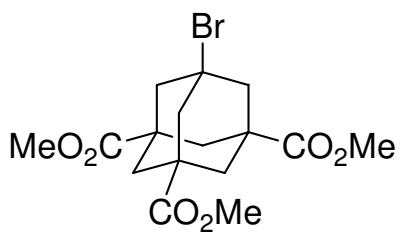

3

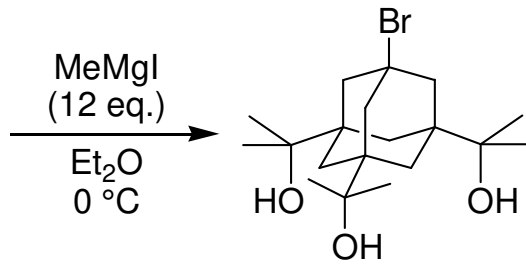

4

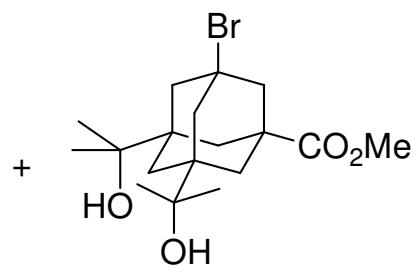

5

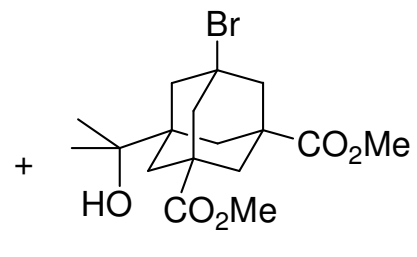

6

3:4:5:6 = 11:20:49:20 (by NMR)

Scheme 1. Reaction of triester 3 with methylmagnesium iodide.

Ishihara ${ }^{13}$ has reported that the nucleophilicity of a Grignard reagent is greatly strengthened by the formation of $\mathrm{R}_{3} \mathrm{MgLi}$ ate complexes with two equivalents of organolithium, which gives "Grignard" products in high yields from ketones that are amenable to reduction or to aldol reaction. The methylation of triester $\mathbf{3}$ using twice the stoichiometric amount of $\mathrm{Me}_{3} \mathrm{MgLi}$ proceeded very cleanly, giving essentially pure triol $\mathbf{4}$ almost quantitatively (Scheme 2).

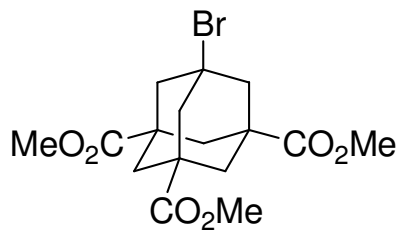

3

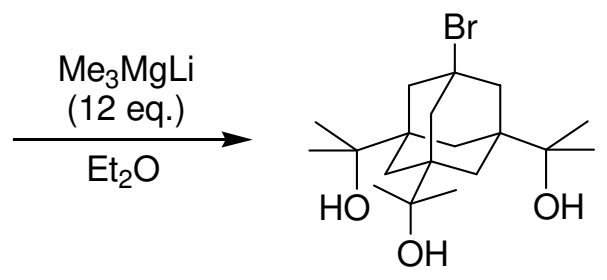

$494 \%$

Scheme 2. Synthesis of trithiol 4 using a magnesium ate complex.

To establish a satisfactory method for the synthesis of trithiol 2, several reactions were examined using tertiary monoalcohol $\mathbf{7}$ as a model compound. An $\mathrm{S}_{\mathrm{N}} 1$-type substitution of trifluoroacetate $\mathbf{8}$ in polar solvents using crown ether-activated potassium thioacetate as a nucleophile gave a complex mixture [Scheme 3, (a)]. Treatment of $\mathbf{8}$ with NaSH-treated Amberlite, which is reportedly pertinent for some tertiary thiols, ${ }^{14}$ was not 
effective, resulting also in unidentified products [Scheme 3, (b)]. These results could be attributed either to facile elimination or to the skeletal rearrangement of intermediate carbocation.
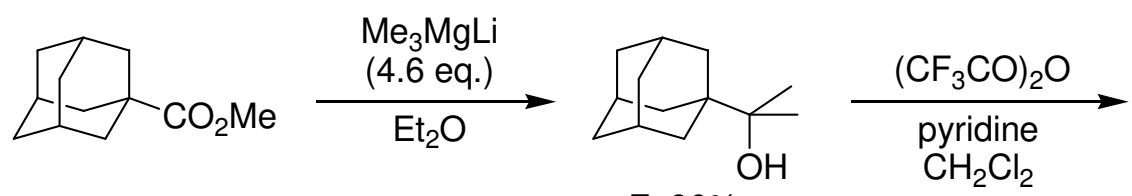

$790 \%$

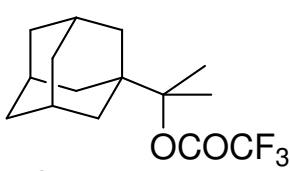

$872 \%$

(a) AcSK, 18-crown-6 in acetone, DMF, or $\mathrm{CH}_{3} \mathrm{CN}$

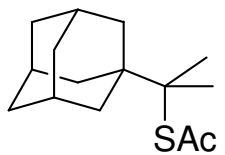

(b) $\mathrm{NaSH}$-treated Amberlite $\mathrm{CH}_{3} \mathrm{CN}$

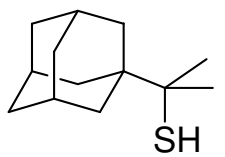

Scheme 3. Attempts at the conversion of alcohol $\mathbf{7}$ to trifluoroacetate 8 and to thiol derivatives.

As an alternative method, Schreiner has demonstrated that tertiary alcohols can be converted to the corresponding thiols by treatment with thiourea in the presence of hydrobromic and acetic acids and subsequent alkaline hydrolysis. ${ }^{15}$ The thiolation of monoalcohol $\mathbf{7}$ gave thiol $\mathbf{9}$ along with a byproduct alkene 10 (Scheme 4). The selectivity was modified by lowering the temperature of the first step (Table 1), giving an optimal yield of $97 \%$ at $25{ }^{\circ} \mathrm{C}$ with no detectable formation of the alkene (entry 6).

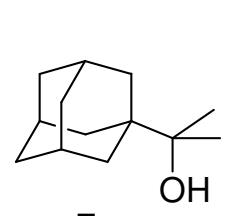

7

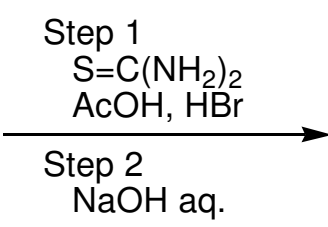

$\mathrm{NaOH}$ aq.

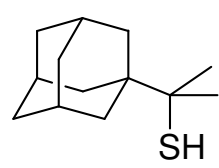

9

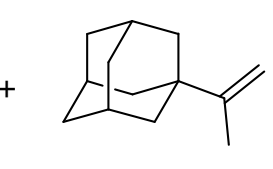

10

Scheme 4. Thiolation of monoalcohol 7 with thiourea treatment.

Table 1. Optimization of the thiolation of 7

\begin{tabular}{cccccc}
\hline \multirow{2}{*}{ entry } & \multirow{2}{*}{$\left.\operatorname{temp}^{\circ}{ }^{\circ} \mathrm{C}\right)^{\mathrm{a}}$} & $\operatorname{time}(\mathrm{h})^{\mathrm{a}}$ & \multicolumn{3}{c}{ molar ratio $^{\mathrm{b}}$} \\
\cline { 4 - 6 } 1 & 130 & 3 & $\mathbf{9}$ & $\mathbf{1 0}$ & $\mathbf{7}$ \\
2 & 95 & 6 & 87.3 & 1.7 & 11.0 \\
3 & 80 & 6 & 90.7 & 1.1 & 8.2 \\
4 & 65 & 6 & 92.8 & 0.8 & 6.4 \\
5 & 50 & 6 & 94.1 & 0.4 & 5.5 \\
6 & 25 & 6 & 95.6 & 0.2 & 4.2 \\
\hline
\end{tabular}

${ }^{a}$ Temperature and time in step $1 .{ }^{b}$ From ${ }^{1} \mathrm{H}$ NMR peak integration. ${ }^{\mathrm{c}}$ Pure thiol 9 was isolated in $90 \%$ yield after separation. 
Following the successful thiolation of model alcohol 7, we applied this method to the synthesis of trithiol 2 (Table 2). Unlike the synthesis of monothiol 9, however, no significant reaction was observed at $25^{\circ} \mathrm{C}$ (entry 1 ). At higher temperatures the ${ }^{1} \mathrm{H}$ NMR spectra of the product mixture showed methyl protons of the $-\mathrm{CMe}{ }_{2} \mathrm{SH}$ group at $\delta$ 1.42. Along with this signal there were also signals of the methyl group of unchanged $-\mathrm{CMe} \mathrm{e}_{2} \mathrm{OH}$ group $\left(\delta 1.21\right.$ ) and the olefinic protons of the $-\mathrm{CMe}=\mathrm{CH}_{2}$ group $(\delta 4.77)$, suggesting the formation of a multicomponent mixture shown in Scheme 5, which consisted of partially thiolated products 11 and 12 and of elimination products such as $\mathbf{1 3}$ and 14. The abundance ratios of these groups were calculated from NMR integrations for reactions under different conditions and are summarized in Table 2.

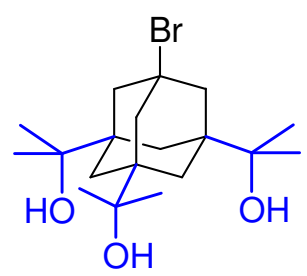

4

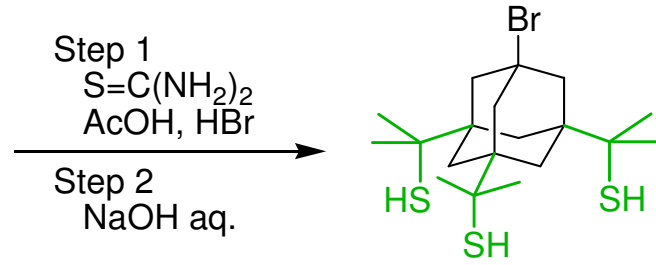

2

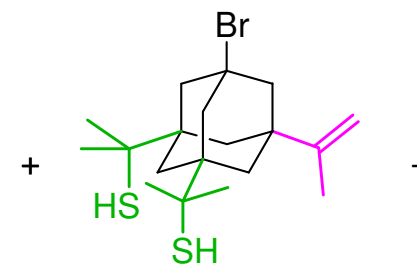

13

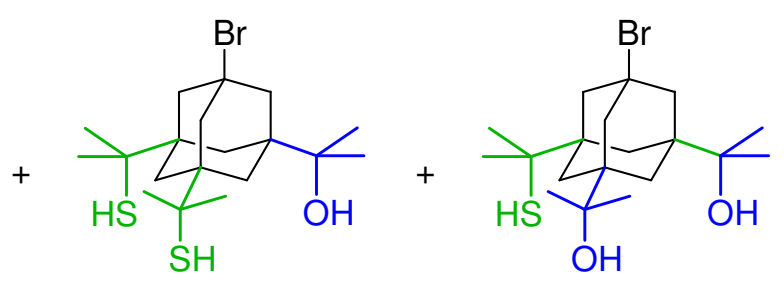

11
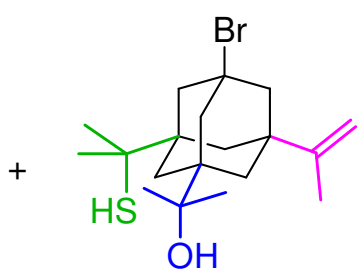

14

12

etc.

Scheme 5. Thiolation of triol 4 by thiourea treatment.

Table 2. Optimizing the trithiolation of 4

\begin{tabular}{|c|c|c|c|c|c|c|c|c|}
\hline \multirow[b]{2}{*}{ entry } & \multicolumn{3}{|c|}{ step 1} & \multicolumn{2}{|c|}{ step 2} & \multicolumn{3}{|c|}{ relative ratio $^{a}$} \\
\hline & $\begin{array}{c}\text { temp } \\
\left({ }^{\circ} \mathrm{C}\right)\end{array}$ & $\begin{array}{c}\text { time } \\
\text { (h) }\end{array}$ & $\begin{array}{c}\text { thiourea } \\
(\text { eq. })^{\text {b }}\end{array}$ & $\begin{array}{c}\text { temp } \\
\left({ }^{\circ} \mathrm{C}\right)\end{array}$ & $\begin{array}{c}\text { time } \\
(\mathrm{h})\end{array}$ & $-\mathrm{CMe}_{2} \mathrm{SH}$ & $-\mathrm{CMe}_{2} \mathrm{OH}$ & $-\mathrm{CMe}=\mathrm{CH}_{2}$ \\
\hline 1 & 25 & 6 & 150 & $\mathrm{rt}$ & 15 & 0 & 94 & 6 \\
\hline 2 & 50 & 6 & 150 & $\mathrm{rt}$ & 15 & 51 & 43 & 6 \\
\hline 3 & 70 & 10 & 150 & $\mathrm{rt}$ & 15 & 70 & 23 & 7 \\
\hline 4 & 70 & 24 & 150 & $\mathrm{rt}$ & 15 & 70 & 22 & 8 \\
\hline 5 & 90 & 10 & 150 & $\mathrm{rt}$ & 15 & 66 & 22 & 12 \\
\hline 6 & 70 & 14 & 150 & 0 & 15 & 70 & 22 & 8 \\
\hline 7 & 70 & 14 & 150 & 0 & 3 & 71 & 20 & 9 \\
\hline 8 & 70 & 14 & 450 & 0 & 3 & 77 & 18 & 5 \\
\hline $9^{c}$ & 70 & 14 & 450 & 0 & 3 & 94 & 4 & 2 \\
\hline
\end{tabular}

${ }^{a}$ From ${ }^{1} \mathrm{H}$ NMR peak integration. ${ }^{\mathrm{b}}$ Molar ratio thiourea/4. ${ }^{\mathrm{c}}$ The product mixture from entry 8 was used as the starting material. The final product ratio was 2:11:13 = 82:12:6. Pure 2 was isolated in $21 \%$ yield after separation.

The conversion from $\mathrm{OH}$ to $\mathrm{SH}$ group increased when the temperature of step 1 was raised (entries 2-5), but a prolonged reaction time at $70{ }^{\circ} \mathrm{C}$ did not change the ratio, because the initial acid-catalyzed substitution 
by thiourea was not completed due to the equilibrium shown in Scheme 6. Since elimination became significant at $90^{\circ} \mathrm{C}$, heating at $70^{\circ} \mathrm{C}$ for $10 \mathrm{~h}$ (entry 3) was considered optimal.

The selectivity of thiol and alkene formation is determined in step 2 and depends on the position of the attack from the hydroxide ion (Scheme 6, A and B). Although the temperature and the time for step 2 were reduced in entries 6 and 7 , no desired modification of the selectivity was achieved.

Next, the equilibrium in step 1 was shifted to the right by the use of a large excess (450 eq.) of thiourea (entry 8), but a complete conversion of $\mathrm{OH}$ to $\mathrm{SH}$ remained a difficult task, and $18 \%$ of $-\mathrm{CMe}_{2} \mathrm{OH}$ remained unchanged. To further convert this to a $-\mathrm{CMe}_{2} \mathrm{SH}$ group, the product mixture of entry 8 was retreated by the same procedure to give a crude trithiol 2 that contained $12 \%$ of $\mathbf{1 1}$ and 6\% of $\mathbf{1 3}$ (entry 9). After removing alcohol 11 by flash chromatography, $\mathbf{2}$ and $\mathbf{1 3}$ could be separated by careful gel permeation chromatography to afford pure 2 in $21 \%$ yield.

Step 1
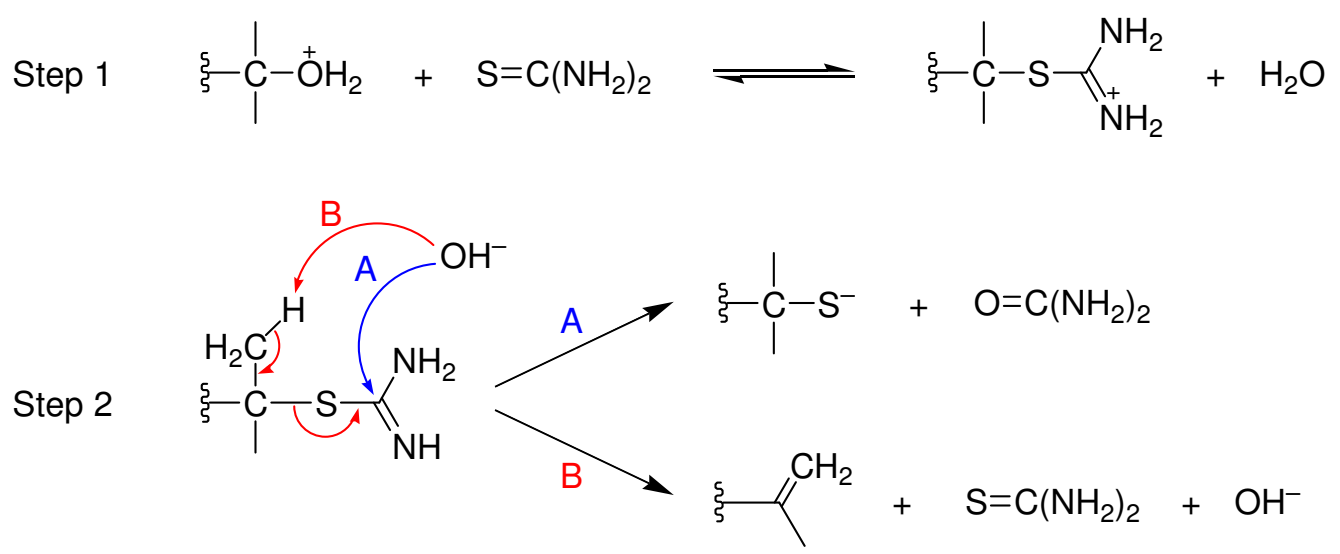

Scheme 6. Two steps of the thiolation of alcohol by thiourea.

\section{Formation of the SAM on Au(111) and XPS characterization}

The SAMs of tripodal trithiol 2 were prepared by immersing a gold substrate, $A u(111)$, with a thickness of 200 $\mathrm{nm}$ on mica, into $0.1 \mathrm{mM}$ solutions in dichloromethane at an ambient temperature for $15 \mathrm{~h}$ or longer. The SAM-modified substrate was washed thoroughly with dichloromethane and air-dried.

The state of the adsorbed thiolate molecules was examined by X-ray photoelectron spectroscopy (XPS) measurement. A sulfur atom bound to gold was reported to show $2 p_{3 / 2}$ and $2 p_{1 / 2}$ signals at $161.9-162.0$ and $163.2 \mathrm{eV}$, respectively, with a 2:1 intensity ratio. ${ }^{16,17}$ The SAM of 2 exhibited a signal at $162.0 \mathrm{eV}$, corresponding to the chemisorbed sulfur atoms (Figure 3). Unbound free SH group, which is expected to appear at $163.5\left(2 \mathrm{p}_{3 / 2}\right)$ and $164.8\left(2 \mathrm{p}_{1 / 2}\right) \mathrm{eV},{ }^{18}$ was not detected, consistent with three-point adsorption. 


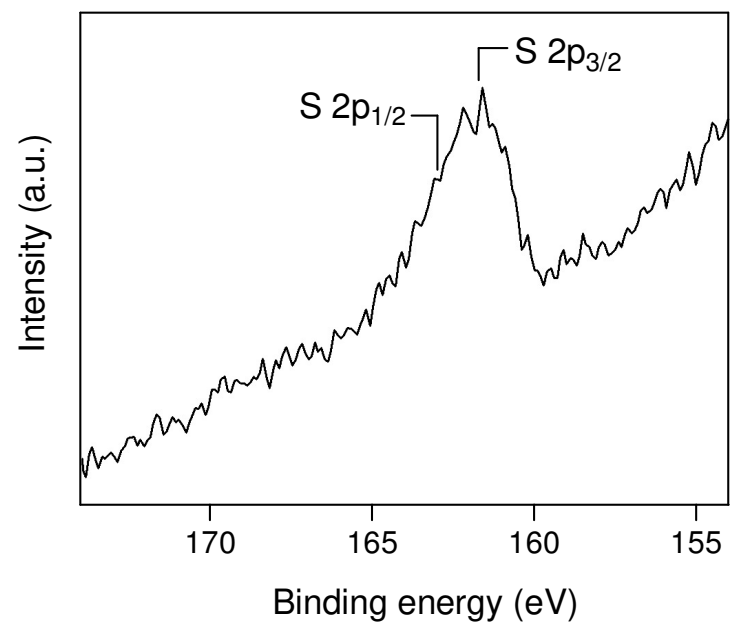

Figure 3. X-ray photoelectron spectrum of the SAM of 2 on $\mathrm{Au}(111)$, prepared from a $\mathrm{CH}_{2} \mathrm{Cl}_{2}$ solution.

\section{Electrochemical reductive desorption of thiolate ion}

Figure 4 shows a cyclic voltammogram of the SAM of 2 recorded in aqueous $\mathrm{KOH}$. A negative current peak due to the desorption of thiolate ion (Equation 1$)^{19,20}$ was observed at $-0.930 \mathrm{~V}$ vs $\mathrm{Ag} / \mathrm{AgCl}$.

$$
\mathrm{RS}-\mathrm{Au}(\mathrm{s})+\mathrm{e}^{-} \rightarrow \mathrm{RS}^{-}+\mathrm{Au}(\mathrm{s})
$$

The observed peak potential and the charge of the reductive desorption of tripod $\mathbf{2}$ are summarized in Table 3, together with the values for $n$-dodecanethiol and our previous trithiol $\mathbf{1}$. The SAM of 2 underwent desorption at a less negative potential than that of $\mathbf{1}$, which may indicate the weakness of the sulfur-gold bonding in the former SAM (vide infra).

In our previous study, the SAM of 1 showed the same reductive charge $\left(100 \mu \mathrm{C} / \mathrm{cm}^{2}\right)^{21}$ as that of $n$ dodecanethiol SAM, because in both SAMs the sulfur atoms are packed in essentially the same hexagonal pattern shown in Figure $1 .{ }^{10}$ Chemisorption of sulfur atoms with the same density is not possible for $\mathbf{2}$ since

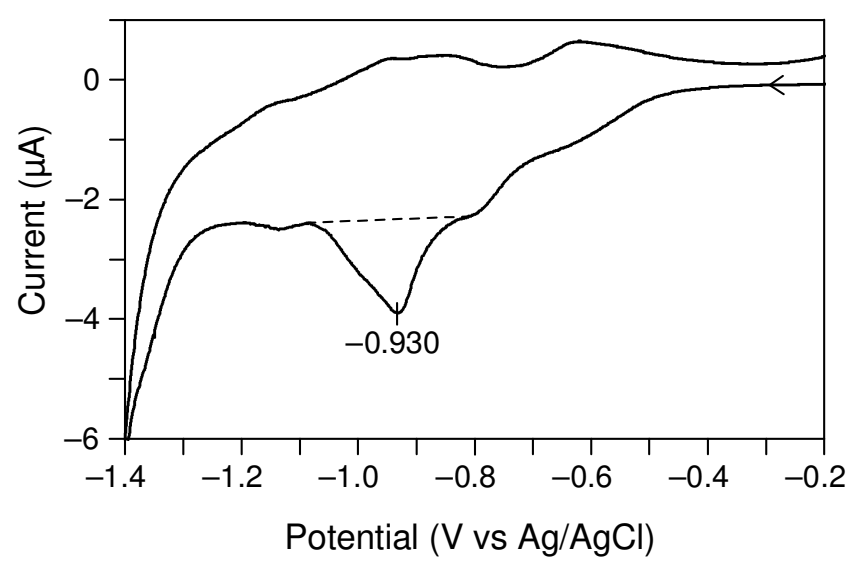

Figure 4. Cyclic voltammogram for the reductive desorption of the SAM of 2 on a Au(111) working electrode in $0.5 \mathrm{M} \mathrm{KOH}$. Scan rate, $20 \mathrm{mV} / \mathrm{s}$. Geometric area of the working electrode, $0.152 \mathrm{~cm}^{2}$. The charge for reductive desorption was calculated from the area below the dotted line. 
the molecule occupies a larger surface area. A reductive charge of $65 \pm 7 \mu \mathrm{C} / \mathrm{cm}^{2}$, was observed for this SAM, indicating that the molecular distance is $(100 / 65)^{1 / 2}=1.24$ times greater than the SAM of 1 . This corresponds to an elongation of average distance to $10.8 \AA$, if the tripod molecules are assumed to be hexagonally arranged.

Table 3. Peak potential and charge for the electrochemical reductive desorption of SAMs derived from thiols on $\mathrm{Au}(111)^{\mathrm{a}}$

\begin{tabular}{|c|c|c|c|c|}
\hline thiol & $\begin{array}{l}\text { peak potential } \\
\text { (V vs Ag/AgCl) }\end{array}$ & $\begin{array}{l}\text { reductive charge } \\
\qquad\left(\mu \mathrm{C} / \mathrm{cm}^{2}\right)^{b, c}\end{array}$ & $\begin{array}{l}\text { intermolecular } \\
\text { distance }(\AA)^{c}\end{array}$ & ref. \\
\hline$n-\mathrm{C}_{12} \mathrm{H}_{25} \mathrm{SH}$ & -1.084 & 100 & 5.0 & 10 \\
\hline 1 & -1.088 & 100 & 8.7 & 10 \\
\hline 2 & -0.930 & $65^{d}$ & 10.8 & this work \\
\hline
\end{tabular}

${ }^{\text {a }}$ Measured by cyclic voltammetry in $0.5 \mathrm{M}$ aqueous $\mathrm{KOH}$. Scan rate, $20 \mathrm{mV} / \mathrm{s}$. ${ }^{\mathrm{b}}$ Calculated by integrating the cathodic wave. ${ }^{\mathrm{c}}$ Uncertainty due to sample-to-sample variations, $\pm 10 \%$. ${ }^{\mathrm{d}}$ Average of four runs.

\section{Theoretical prediction of molecular packing in the monolayer on gold}

The adsorption energy $\left(E_{\text {ads }}\right)$ of adamantane tripod molecules $\operatorname{Ad}\left(C_{2} S\right)_{3}(X=H, M e)$ on a gold surface is expressed as follows.

$$
E_{\text {ads }}=E\left[\mathrm{Ad}\left(\mathrm{CX}_{2} \mathrm{~S}\right)_{3} / \mathrm{Au} \text { layer }\right]-E\left[\mathrm{Ad}\left(\mathrm{CX}_{2} \mathrm{~S}\right)_{3}\right]-E(\text { Au layer })
$$

In this equation, $E\left[A d\left(C X_{2} S\right)_{3} / A u\right.$ layer], $E\left[A d\left(C X_{2} S\right)_{3}\right]$, and $E(A u$ layer $)$ are the energies of Au layer with adsorbed $\mathrm{Ad}\left(\mathrm{CX}_{2} \mathrm{~S}\right)_{3}$, free $\mathrm{Ad}\left(\mathrm{CX}_{2} \mathrm{~S}\right)_{3}$, and Au layer, respectively. ${ }^{22}$

Initial calculations of tripod-adsorbed surface structures were performed for $\mathrm{Ad}\left(\mathrm{CX}_{2} \mathrm{~S}\right)_{3}$ molecules $(\mathrm{X}=\mathrm{H}$ or $\mathrm{Me}$ ) adsorbed onto a Au monolayer composed of 19, 27, or 37 Au atoms as models of the Au(111) surface (Figure 5). Several energy minima were obtained (see Tables S1 and S2 in supporting information), among which $\mathbf{X} \mathbf{1}$ and $\mathbf{X} \mathbf{2}$ were found to be the most stable geometries for $\mathrm{Ad}\left(\mathrm{CH}_{2} \mathrm{~S}\right)_{3} / \mathrm{Au}$ layer and $\mathrm{Ad}\left(\mathrm{CMe}_{2} \mathrm{~S}\right)_{3} / \mathrm{Au}$ layer, respectively (Figure 6).
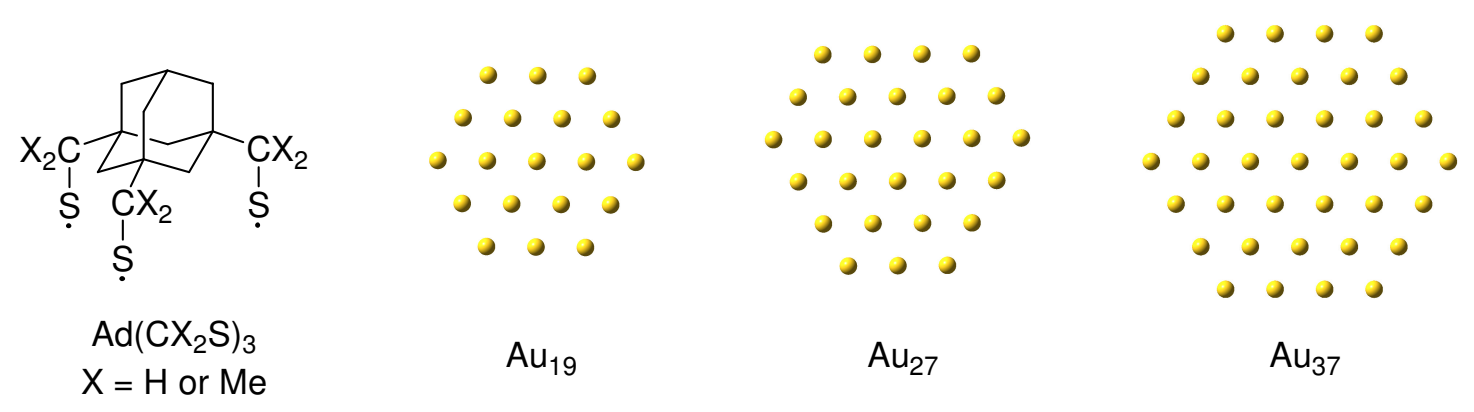

Figure 5. Structures of $\operatorname{Ad}\left(C_{2} S\right)_{3}$ and finite Au layers. 


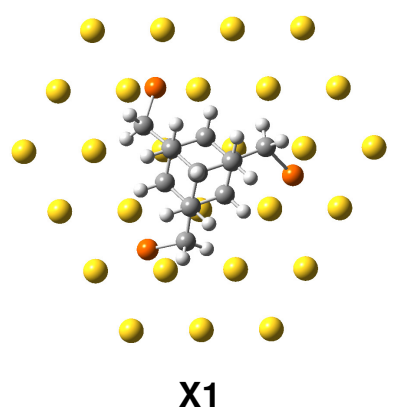

$\mathrm{Ad}\left(\mathrm{CH}_{2} \mathrm{~S}\right)_{3}$ on $\mathrm{Au}_{27}$

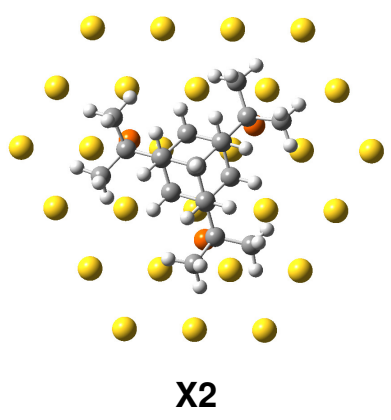

$\mathrm{Ad}\left(\mathrm{CMe}_{2} \mathrm{~S}\right)_{3}$ on $\mathrm{Au}_{27}$

Figure 6. Structures of $\mathrm{Ad}\left(\mathrm{CH}_{2} \mathrm{~S}\right)_{3}$ and $\mathrm{Ad}\left(\mathrm{CMe}_{2} \mathrm{~S}\right)_{3}$ on the $\mathrm{Au}_{27}$ monolayer optimized by the DFT method.

In the next step, single-point energy calculations for the infinite SAM on $A u(111)$ were conducted under two-dimensional periodic boundary conditions (PBC) using the geometries $\mathbf{X} \mathbf{1}$ and $\mathbf{X} \mathbf{2}$ (Table 4). Among eight possible orientations for the SAM of $\mathrm{Ad}\left(\mathrm{CH}_{2} \mathrm{~S}\right)_{3}$ (see Table S4 in Supporting Information for complete results), the $(3 \times 3) R 60^{\circ}$ lattice showed the most negative $E_{\text {ads }}(-4.28 \mathrm{kcal} / \mathrm{mol}$ per $\mathrm{Au}$ atom $)$. The nearest molecular distance was $8.64 \AA$, and the shortest intermolecular distances of $\mathrm{H}-\mathrm{H}$ and S-S were $2.67 \AA$ and $3.99 \AA$, respectively, which are longer than the van der Waals diameters of $\mathrm{H}$ and $\mathrm{S}$ atoms. ${ }^{23}$ These results show that the $(3 \times 3) \mathrm{R}^{\circ} 0^{\circ}$ orientation can provide a stable $\mathrm{SAM}$ from $\mathrm{Ad}\left(\mathrm{CH}_{2} \mathrm{~S}\right)_{3}$, which is consistent with the experimental observation of this arrangement for the SAM of molecule $1 .^{10}$

Table 4. Adsorption energy $E_{\text {ads }}$ by PBC calculations for the SAMs of $\mathrm{Ad}\left(\mathrm{CH}_{2} \mathrm{~S}\right)_{3}$ and $\mathrm{Ad}\left(\mathrm{CMe}_{2} \mathrm{~S}\right)_{3}$ on $\mathrm{Au}(111)^{\mathrm{a}}$

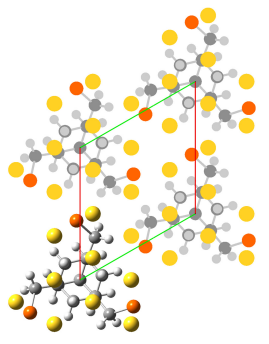

(i)

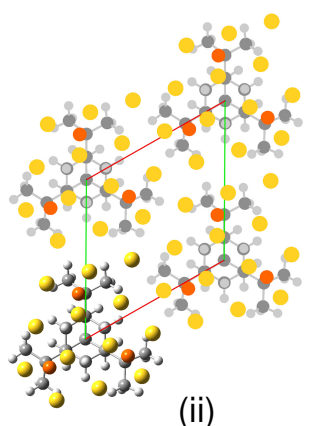

(ii)

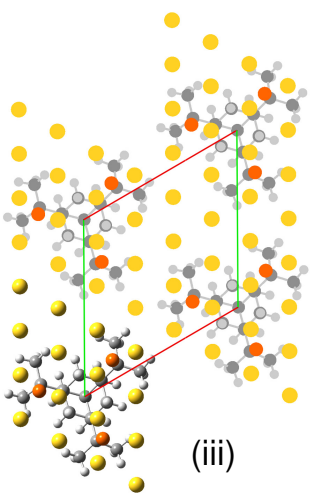

(iii)

\begin{tabular}{|c|c|c|c|c|c|c|}
\hline \multirow[b]{2}{*}{$\begin{array}{l}\text { adsorbed } \\
\text { molecule }\end{array}$} & \multirow[b]{2}{*}{ unit cell $^{\mathrm{b}}$} & \multirow[b]{2}{*}{$\begin{array}{l}\text { structure } \\
\text { of SAM }\end{array}$} & \multirow{2}{*}{$\begin{array}{c}\text { nearest } \\
\text { molecular } \\
\text { distance }(\AA)\end{array}$} & \multirow{2}{*}{$\begin{array}{c}\text { number of Au } \\
\text { atoms per } \\
\text { unit cell }\end{array}$} & \multicolumn{2}{|c|}{$E_{\text {ads }}(\mathrm{kcal} / \mathrm{mol})^{\mathrm{c}}$} \\
\hline & & & & & $\begin{array}{c}\text { per } \\
\text { unit cell }\end{array}$ & $\begin{array}{c}\text { per } \\
\text { Au atom }\end{array}$ \\
\hline $\mathrm{Ad}\left(\mathrm{CH}_{2} \mathrm{~S}\right)_{3}$ & $(3 \times 3) \mathrm{R} 60^{\circ}$ & (i) & 8.64 & 9 & -38.5 & -4.28 \\
\hline \multirow[t]{2}{*}{$\mathrm{Ad}\left(\mathrm{CMe}_{2} \mathrm{~S}\right)_{3}$} & $(\sqrt{13} \times \sqrt{13}) R 46.1^{\circ}$ & (ii) & 10.38 & 13 & -26.5 & -2.04 \\
\hline & $(4 \times 4) \mathrm{R} 60^{\circ}$ & (iii) & 11.52 & 16 & -25.6 & -1.60 \\
\hline
\end{tabular}

${ }^{a}$ UBLYP/3-21G for $\mathrm{C}, \mathrm{H}$, and $\mathrm{S}$ atoms and LanL2MB for $\mathrm{Au}$ atom. The Au-Au distance was fixed at $2.88 \AA$ during structural optimization. ${ }^{b}$ Wood's notation. ${ }^{24,25}{ }^{c} E_{\text {ads }}=E\left[A d\left(C_{2} S\right)_{3} / A u\right.$ layer $]-E\left[A d\left(C X_{2} S\right)_{3}\right]-E(A u$ layer $)(X=$ $\mathrm{H}$ or $\mathrm{Me}) . E(\mathrm{Au}$ layer $)$ and $E\left[\mathrm{Ad}\left(\mathrm{CX}_{2} \mathrm{~S}\right)_{3}\right]$ were also calculated and are given in Tables $\mathrm{S} 6$ and $\mathrm{S} 7$, respectively. 
For the hexamethylated molecule $\mathrm{Ad}\left(\mathrm{CMe}_{2} \mathrm{~S}\right)_{3}$, the $(3 \times 3) \mathrm{R} 60^{\circ}$ lattice is impossible due to severe repulsion between adjacent molecules. On the other hand, $(4 \times 4) \mathrm{R} 60^{\circ}$ showed a negative $E_{\text {ads }}$ of $-1.60 \mathrm{kcal} / \mathrm{mol}$ (per Au atom), and the value for $(\sqrt{13} \times \sqrt{13}) \mathrm{R} 46.1^{\circ},-2.04 \mathrm{kcal} / \mathrm{mol}$ was lowest. The nearest molecular distances in these structures were 11.52 and $10.38 \AA$, respectively suggesting that the molecular packing of the SAM of trithiol 2 would fall within this range. This agrees well with the experimental value of $10.8 \AA$, from cyclic voltammetry. In addition, the calculated adsorption energies per unit cell suggest that the Au-S bond is weaker in the $\mathrm{Ad}\left(\mathrm{CMe}_{2} \mathrm{~S}\right)_{3}$ system. It is likely that the $\mathrm{S}$ atoms in this molecule are unable to take the most preferred positions on the $\mathrm{Au}(111)$ surface due to the steric effect of the methyl groups. This explains the observed less-negative peak potential of reductive desorption.

\section{Conclusions}

The synthesis of an area-demanding tripodal trithiol containing peripheral methyl groups $\mathbf{2}$ was achieved via exhaustive methylation of starting triester $\mathbf{3}$ using a magnesium ate complex to form triol $\mathbf{4}$ with subsequent thiourea-mediated thiolation. A SAM was prepared from this trithiol and was characterized by XPS and cyclic voltammetry. The observed charge for the reductive desorption and theoretical estimation of molecular packing by the PBC-DFT method indicated that $\mathbf{2}$ is distributed on SAM with a nearest molecular distance of ca. $10.8 \AA$. This length is $24 \%$ greater than we previously reported ( $8.7 \AA$ ) for the SAM of non-methylated tripod molecule 1 . The present results will allow the preparation of the monolayers of large functional molecular units without undesirable lateral interactions between neighboring molecular units.

\section{Experimental Section}

General. Anhydrous solvents used for synthesis were prepared by standard methods. Other reagents were used as received, unless otherwise noted. NMR spectra were obtained using either a JEOL JNM-A500 ( ${ }^{1} \mathrm{H}, 500$ $\left.\mathrm{MHz} ;{ }^{13} \mathrm{C}, 125 \mathrm{MHz}\right)$ or a JEOL JNM-AL300 $\left({ }^{1} \mathrm{H}, 300 \mathrm{MHz} ;{ }^{13} \mathrm{C}, 75.5 \mathrm{MHz}\right)$ instrument. High-resolution mass spectra were obtained using a JEOL JMS-600H spectrometer. The IR spectra were recorded on a JASCO FT/IR4200 spectrophotometer with an attenuated total reflection (ATR) mode. Preparative gel permeation chromatography was performed in a recycle mode using a Shodex $\mathrm{H}-2001$ column $(20 \mathrm{~mm} \times 50 \mathrm{~cm})$.

2-(1-Adamantyl)-2-propanol (7). ${ }^{26}$ A solution of $\mathrm{CH}_{3} \mathrm{Mgl}$ in ether $\left(9 \mathrm{~mL}\right.$ ) was prepared from $0.39 \mathrm{~mL}$ of $\mathrm{CH}_{3}$ $(6.3 \mathrm{mmol})$ and $155 \mathrm{mg}(6.4 \mathrm{mmol})$ of magnesium turnings, and then $11.0 \mathrm{~mL}$ of $1.13 \mathrm{M} \mathrm{CH}_{3} \mathrm{Li}$ in ether $(12.4$ mmol) was added at $-40{ }^{\circ} \mathrm{C}$ over $20 \mathrm{~min}$. The mixture was then stirred at $-40{ }^{\circ} \mathrm{C}$ for a further $1 \mathrm{~h}$. Then a solution of 1-(methoxycarbonyl)adamantane $(262 \mathrm{mg}, 1.35 \mathrm{mmol})$ in ether $(10 \mathrm{ml})$ was added at $-40{ }^{\circ} \mathrm{C}$ over $15 \mathrm{~min}$. After being stirred at room temperature for $1 \mathrm{~h}$, the mixture was quenched with sat. $\mathrm{NH}_{4} \mathrm{Cl}$ and extracted with ether. The organic layer was washed with $5 \% \mathrm{NaCl}$ and dried $\left(\mathrm{Na}_{2} \mathrm{SO}_{4}\right)$. The solvent was evaporated, and the residue was purified by flash column chromatography on silica gel $\left(\mathrm{CHCl}_{3}\right)$ to give 7 (236 $\mathrm{mg}, 90 \%)$ as colorless crystals, $\mathrm{mp} 70-71^{\circ} \mathrm{C}$. IR (ATR, cm $\left.{ }^{-1}\right), 3478,2921,2892,2849,1445,1363,1142,929$, 887; ${ }^{1} \mathrm{H}$ NMR (500 MHz, C6 $\left.\mathrm{D}_{6}\right), \delta 1.92(\mathrm{~s}, 3 \mathrm{H}), 1.65$ (d, J $\left.11.6 \mathrm{~Hz}, 3 \mathrm{H}\right), 1.57$ (d, J $\left.11.6 \mathrm{~Hz}, 3 \mathrm{H}\right), 1.54$ (d, J $2.4 \mathrm{~Hz}$, $6 \mathrm{H}), 0.99(\mathrm{~s}, 6 \mathrm{H}), 0.71\left(\mathrm{~s}, 1 \mathrm{H}\right.$, disappeared by $\mathrm{D}_{2} \mathrm{O}$ treatment); ${ }^{13} \mathrm{C} N M R\left(75.5 \mathrm{MHz}, \mathrm{C}_{6} \mathrm{D}_{6}\right), \delta 73.9,38.9,37.4$, 36.4, 29.0, 24.5. The observed ${ }^{1} \mathrm{H}$ and ${ }^{13} \mathrm{C}$ NMR spectra agreed with those in the literature. ${ }^{26,27}$ 
2-(1-Adamantyl)-2-propyl trifluoroacetate (8). ${ }^{28}$ Trifluoroacetic anhydride $(0.18 \mathrm{~mL}, 1.3 \mathrm{mmol})$ was added dropwise to a solution of alcohol $7(200 \mathrm{mg}, 1.03 \mathrm{mmol})$ and pyridine $(4 \mathrm{~mL})$ in $\mathrm{CH}_{2} \mathrm{Cl}_{2}(4 \mathrm{~mL})$, and the reaction mixture was stirred at $0{ }^{\circ} \mathrm{C}$ for $2 \mathrm{~h}$. The mixture was washed with cold $10 \% \mathrm{HCl}$ and cold $5 \% \mathrm{NaHCO}_{3}$ and dried $\left(\mathrm{Na}_{2} \mathrm{SO}_{4}\right)$. The solvent was evaporated, and the residue was purified by flash column chromatography on silica gel $\left(\mathrm{CHCl}_{3}\right)$ to give $8(214 \mathrm{mg}, 72 \%)$ as a colorless oil. IR (ATR, $\left.\mathrm{cm}^{-1}\right), 2908,1774,1454,1373,1213,1161,1123$, 1074; ${ }^{1} \mathrm{H}$ NMR (500 MHz, $\left.\mathrm{C}_{6} \mathrm{D}_{6}\right), \delta 1.81(\mathrm{~s}, 3 \mathrm{H}), 1.54$ (d, J $\left.12.2 \mathrm{~Hz}, 3 \mathrm{H}\right), 1.44$ (d, J $\left.11.6 \mathrm{~Hz}, 3 \mathrm{H}\right), 1.40$ (d, J $2.4 \mathrm{~Hz}$, $6 \mathrm{H}), 1.26(\mathrm{~s}, 6 \mathrm{H}) ;{ }^{13} \mathrm{C}$ NMR $\left(125 \mathrm{MHz}, \mathrm{C}_{6} \mathrm{D}_{6}\right), \delta 156.4\left(\mathrm{q},{ }^{2} J_{\mathrm{CF}} 40.3 \mathrm{~Hz}\right), 115.4\left(\mathrm{q},{ }^{1} J_{\mathrm{CF}} 287.6 \mathrm{~Hz}\right), 93.8,39.8,36.9$, $35.8,28.6,19.2$. The observed ${ }^{1} \mathrm{H}$ NMR spectrum agreed with that in the literature. ${ }^{28}$

2-(1-Adamantyl)-2-propanethiol (9). Alcohol 7 (29.9 mg, $0.15 \mathrm{mmol}$ ) was added to a solution of thiourea (1.75 $\mathrm{g}, 23 \mathrm{mmol})$ in a mixture of acetic acid $(8 \mathrm{~mL})$ and $47 \%$ aqueous $\mathrm{HBr}(3.8 \mathrm{~mL})$. After being stirred at $25^{\circ} \mathrm{C}$ for 6 $\mathrm{h}$, the mixture was poured into cold $15 \% \mathrm{NaOH}(90 \mathrm{~mL})$ and was stirred at room temperature for $16 \mathrm{~h}$. The resultant mixture was cooled to $0{ }^{\circ} \mathrm{C}$ and was acidified to $\mathrm{pH} 2-3$ by the addition of $50 \% \mathrm{H}_{2} \mathrm{SO}_{4}$ with the temperature kept below $10{ }^{\circ} \mathrm{C}$. The product was extracted with $\mathrm{CHCl}_{3}$, and the organic layer was washed with $5 \% \mathrm{NaHCO}_{3}$ and $5 \% \mathrm{NaCl}$ and dried $\left(\mathrm{Na}_{2} \mathrm{SO}_{4}\right)$. The solvent was evaporated, and the residue was purified by flash column chromatography on silica gel $\left(\mathrm{CHCl}_{3}\right)$ to give $9(29 \mathrm{mg}, 90 \%)$ as pale yellow crystals, mp 119$121{ }^{\circ} \mathrm{C}$. IR (ATR, cm ${ }^{-1}$ ), 2900, 2678, 1446, 1361, 1343, 1129; ${ }^{1} \mathrm{H}$ NMR (500 MHz, $\left.\mathrm{C}_{6} \mathrm{D}_{6}\right), \delta 1.90$ (s, $\left.3 \mathrm{H}\right), 1.63$ (d, J $2.4 \mathrm{~Hz}, 6 \mathrm{H}), 1.60(\mathrm{~d}, J 12.2 \mathrm{~Hz}, 3 \mathrm{H}), 1.51(\mathrm{~d}, J 11.6 \mathrm{~Hz}, 3 \mathrm{H}), 1.29(\mathrm{~s}, 1 \mathrm{H}), 1.21(\mathrm{~s}, 6 \mathrm{H}) ;{ }^{13} \mathrm{C} \mathrm{NMR}\left(125 \mathrm{MHz}, \mathrm{C}_{6} \mathrm{D}_{6}\right), \delta$ 52.1, 38.6, 37.1, 36.7, 29.1, 27.8; HRMS (El+, $m / z)$ for $\mathrm{C}_{13} \mathrm{H}_{22} \mathrm{~S}\left(\mathrm{M}^{+}\right)$: calcd, 210.1442; found, 210.1450.

1-Bromo-3,5,7-tris(1-hydroxy-1-methylethyl)adamantane (4). A solution of $\mathrm{CH}_{3} \mathrm{Mgl}$ in ether (12 $\left.\mathrm{mL}\right)$ was prepared from $0.38 \mathrm{~mL}$ of $\mathrm{CH}_{3} \mathrm{l}(6.1 \mathrm{mmol})$ and $152 \mathrm{mg}(6.3 \mathrm{mmol})$ of magnesium turnings, and then $11.0 \mathrm{~mL}$ of $1.13 \mathrm{M} \mathrm{CH}_{3} \mathrm{Li}$ in ether $(12.4 \mathrm{mmol})$ was added at $-40{ }^{\circ} \mathrm{C}$ over $30 \mathrm{~min}$. The mixture was then stirred at $-40^{\circ} \mathrm{C}$ for further $1 \mathrm{~h}$. Then a solution of triester $3(201 \mathrm{mg}, 0.52 \mathrm{mmol})$ in ether $(10 \mathrm{ml})$ was added at $-40^{\circ} \mathrm{Cover} 20 \mathrm{~min}$. After being stirred at room temperature for $1 \mathrm{~h}$, the mixture was quenched with sat. $\mathrm{NH}_{4} \mathrm{Cl}$ and extracted with ether. The organic layer was washed with $5 \% \mathrm{NaCl}$ and dried $\left(\mathrm{Na}_{2} \mathrm{SO}_{4}\right)$. The solvent was evaporated, and the residue was purified by flash column chromatography on silica gel $\left(\mathrm{CHCl}_{3}\right)$ to give 4 (190 $\left.\mathrm{mg}, 94 \%\right)$ as colorless crystals, mp 200-201 ${ }^{\circ} \mathrm{C}$ (from acetone-CHCl $)$. IR (ATR, $\mathrm{cm}^{-1}$ ), 3365, 2969, 1377, 1143, 1121, 948, 910; ${ }^{1} \mathrm{H}$ NMR (300 MHz, acetone- $\left.d_{6}\right), \delta 2.14(\mathrm{~s}, 6 \mathrm{H}), 1.59(\mathrm{~d}, J 12.3 \mathrm{~Hz}, 3 \mathrm{H}), 1.45(\mathrm{~d}, J 12.1 \mathrm{~Hz}, 3 \mathrm{H}), 1.14(\mathrm{~s}, 18 \mathrm{H}), \mathrm{The} \mathrm{OH}$ signal was not observed due to rapid proton exchange with water in the solvent; ${ }^{13} \mathrm{C} \mathrm{NMR}(75.5 \mathrm{MHz}$, acetone$\left.d_{6}\right), \delta 73.9,72.8,48.6,45.7,34.2,25.2 ; \mathrm{HRMS}(\mathrm{EI}+, \mathrm{m} / z)$ for $\mathrm{C}_{19} \mathrm{H}_{27}\left(\left[\mathrm{M}-\mathrm{Br}-3 \mathrm{H}_{2} \mathrm{O}\right]^{+}\right)^{29}$ : calcd, 255.2113; found, 255.2136.

1-Bromo-3,5,7-tris(1-mercapto-1-methylethyl)adamantane (2). Triol 4 (39.1 mg, $0.10 \mathrm{mmol}$ ) was added to a solution of thiourea (3.46 g, $45 \mathrm{mmol})$ in a mixture of acetic acid $(5 \mathrm{~mL})$ and $47 \%$ aqueous $\mathrm{HBr}(2.5 \mathrm{~mL})$. After being stirred at $70{ }^{\circ} \mathrm{C}$ for $14 \mathrm{~h}$, the mixture was added to cold $15 \% \mathrm{NaOH}(60 \mathrm{~mL})$ and was stirred at $0{ }^{\circ} \mathrm{C}$ for $3 \mathrm{~h}$. The resultant mixture was acidified to $\mathrm{pH} 2-3$ by the addition of $50 \% \mathrm{H}_{2} \mathrm{SO}_{4}$ with the temperature kept below $10{ }^{\circ} \mathrm{C}$, and extracted with $\mathrm{CHCl}_{3}$. The organic layer was washed with $5 \% \mathrm{NaHCO}_{3}$ and $5 \% \mathrm{NaCl}$ and dried $\left(\mathrm{Na}_{2} \mathrm{SO}_{4}\right)$. The solvent was then evaporated to give $31.9 \mathrm{mg}$ of a mixture composed of trithiol 2 and partially thiolated products. To achieve complete thiolation, this mixture was treated again using the same amount of thiourea under the same conditions to give $32.0 \mathrm{mg}$ of crude trithiol $\mathbf{2}$.

The above procedure was repeated four times, and the combined crude $\mathbf{2}$ (136 mg) was purified by flash column chromatography on silica gel ( $\mathrm{AcOEt}-\mathrm{CHCl}_{3}$ 1:3) and subsequently by gel permeation chromatography to give pure 2 (37.6 mg, 21\%) as pale yellow crystals, mp 202-204 ${ }^{\circ} \mathrm{C}$. IR (ATR, $\mathrm{cm}^{-1}$ ), 2955, 2548, 1461, 1368, 1347, 1122, 1024; ${ }^{1} \mathrm{H}$ NMR (500 MHz, C $\left.6 \mathrm{D}_{6}\right), \delta 1.54$ (d, J $\left.11.6 \mathrm{~Hz}, 3 \mathrm{H}\right), 1.49$ (d, J $\left.12.2 \mathrm{~Hz}, 3 \mathrm{H}\right), 1.42$ (s, $\left.6 \mathrm{H}\right), 1.33$ (s, $3 \mathrm{H}), 1.20(\mathrm{~s}, 18 \mathrm{H}) ;{ }^{13} \mathrm{C}$ NMR $\left(75.5 \mathrm{MHz}, \mathrm{CDCl}_{3}\right), \delta 71.4,52.0,43.1,42.9,34.2,28.3 ; \mathrm{HRMS}(\mathrm{El}+, \mathrm{m} / \mathrm{z})$ for $\mathrm{C}_{18} \mathrm{H}_{29} \mathrm{~S}_{3}$ $\left(\left[\mathrm{M}-\mathrm{Br}-\mathrm{CH}_{4}\right]^{+}\right)^{29}$ : calcd, 341.1431; found, 341.1402. 
Preparation of self-assembled monolayer on gold. Gold substrates with a (111) surface were prepared via vacuum vapor deposition of gold (99.99\%) onto freshly cleaved mica sheets (0.05 mm thickness) under high vacuum $\left(<10^{-3} \mathrm{~Pa}\right)$ at a substrate temperature of $580{ }^{\circ} \mathrm{C}$. The deposition was carried out until a $200 \mathrm{~nm}$ thickness was obtained. The substrate was annealed at $530{ }^{\circ} \mathrm{C}$ for $8 \mathrm{~h}$ under air to minimize surface contamination and defects, and was then immersed into $0.1 \mathrm{mM}$ solutions of trithiol 2 at ambient temperature for $15 \mathrm{~h}$ or longer. The obtained substrate was washed thoroughly with the same solvent and airdried.

Cyclic voltammetry. The SAM-modified gold substrate was mounted at the bottom of a cone-shaped cell using an O-ring to serve as a working electrode. The area of the electrode exposed to the electrolyte was $0.152 \mathrm{~cm}^{2}$ (4.4 mm diameter circle). The reduction wave of thiolate desorption was monitored using $0.5 \mathrm{M}$ aqueous $\mathrm{KOH}$ as an electrolyte and a $\mathrm{Ag} / \mathrm{AgCl}$ reference electrode. The electrolyte solution was deaerated by bubbling argon for 10 min before scanning. Voltammograms were recorded using a BAS ALS600C electrochemical analyzer.

X-ray photoelectron spectroscopy. The XPS data were recorded with a Shimadzu ESCA-3400 spectrometer using a Mg Ka X-ray source ( $h v 1253.6 \mathrm{eV}$ ). The spectra for S $2 p$ and Au $4 \mathrm{f}$ were acquired at a pass energy of 75 $\mathrm{eV}$. The photoelectron takeoff angle and the energy resolution were $90^{\circ}$ and $0.1 \mathrm{eV}$, respectively. The binding energies were corrected based on $\mathrm{Au} 4 \mathrm{f}_{7 / 2}$ at $83.93 \mathrm{eV}^{30}$

DFT calculations. DFT (density function theory) calculations ${ }^{31}$ were performed with the Gaussian 03 program. ${ }^{32}$ Optimized structures and their energies were calculated using the UB3LYP method along with the 3-21G basis set for $\mathrm{C}, \mathrm{H}$, and $\mathrm{S}$ atoms and the LanL2MB basis set for $\mathrm{Au}$. The structures of one $\mathrm{Ad}\left(\mathrm{CX}_{2} \mathrm{~S}\right)_{3}(\mathrm{X}=\mathrm{H}$ or $\mathrm{Me})$ molecule on the finite gold monolayers $\left(\mathrm{Au}_{17}, \mathrm{Au}_{27}\right.$, or $\left.\mathrm{Au}_{37}\right)$ were optimized with symmetric restriction with frozen geometries of finite gold atomic monolayers, where Au-Au distance was fixed at $2.88 \AA$ as a bulk parameter of the $\mathrm{Au}(111)$ surface. ${ }^{1}$ All stationary points were verified to be either minima (number of imaginary frequency $=0$ ) or transition states by frequency calculations. Single-point calculations of the infinite gold monolayers adsorbed with $\mathrm{Ad}\left(\mathrm{CX}_{2} \mathrm{~S}\right)_{3}(\mathrm{X}=\mathrm{H}$ or $\mathrm{Me}$ ) molecules were also performed using PBC (periodic boundary conditions) calculations with the optimized geometries of $\mathbf{X} \mathbf{1}$ and $\mathbf{X} \mathbf{2}$ by the UBLYP method at the same basis sets.

\section{Acknowledgements}

This work was supported by the Grand-in-Aid for Scientific Research (C) (15K05474) from the Ministry of Education, Culture, Sports, Science and Technology, Japan.

\section{Supplementary Material}

${ }^{1} \mathrm{H}$ and ${ }^{13} \mathrm{C}$ NMR spectra for new compounds and the detailed results of DFT calculations.

\section{References and Notes}

1. Poirier, G. E. Chem. Rev. 1997, 97, 1117-1127.

https://doi.org/10.1021/cr960074m

2. Love, J. C.; Estroff, L. A.; Kriebel, J. K.; Nuzzo, R. G.; Whitesides, G. M. Chem. Rev. 2005, 105, $1103-1169$. 
https://doi.org/10.1021/cr0300789

3. Kind, M.; Wöll, C. Prog. Surf. Sci. 2009, 84, 230-278.

https://doi.org/10.1016/j.progsurf.2009.06.001

4. Gooding, J. J.; Mearns, F.; Yang, W.; Liu, J. Electroanalysis 2003, 15, 81-96.

https://doi.org/10.1002/elan.200390017

5. Bertin, P. A.; Ahrens, M. J.; Bhavsar, K.; Georganopoulou, D.; Wunder, M.; Blackburn, G. F.; Meade, T. J. Org. Lett. 2010, 12, 3372-3375.

https://doi.org/10.1021/ol101180r

6. van Delden, R. A.; ter Wiel, M. K. J.; Pollard, M. M.; Vicario, J.; Koumura. N.; Feringa, B. L. Nature 2005, 437, 1337-1340.

https://doi.org/10.1038/nature04127

7. Kay, E. R.; Leigh, D. A.; Zerbetto, F. Angew. Chem. Int. Ed. 2007, 46, 72-191.

https://doi.org/10.1002/anie.200504313

8. Tour, J. M. Acc. Chem. Res. 2000, 33, 791-804.

https://doi.org/10.1021/ar0000612

9. McCreery, R. L. Chem. Mater. 2004, 16, 4477-4496.

https://doi.org/10.1021/cm049517q

10. Kitagawa, T.; Idomoto, Y.; Matsubara, H.; Hobara, D.; Kakiuchi, T.; Okazaki, T.; Komatsu, K. J. Org. Chem. 2006, 71, 1362-1369.

https://doi.org/10.1021/jo051863j

11. Kitagawa, T.; Matsubara, H.; Komatsu, K.; Hirai, K.; Okazaki, T.; Hase, T. Langmuir 2013, $29,4275-4282$.

https://doi.org/10.1021/la305092g

12. Kitagawa, T.; Matsubara, H.; Okazaki, T.; Komatsu, K. Molecules 2014, 19, 15298-15313.

https://doi.org/10.3390/molecules190915298

13. Hatano, M.; Matsumura, T.; Ishihara, K. Org. Lett. 2005, 7, 573-576.

https://doi.org/10.1021/ol047685i

14. Bandgar, B. P.; Sadavarte, V. S.; Uppalla, L. S. Chem. Lett. 2000, 29, 1304-1305.

https://doi.org/10.1246/cl.2000.1304

15. Tkachenko, B. A.; Fokina, N. A.; Chernish, L. V.; Dahl, J. E. P.; Liu, S.; Carlson, R. M. K.; Fokin, A. A.; Schreiner, P. R. Org. Lett. 2006, 8, 1767-1770.

https://doi.org/10.1021/ol053136g

16. Castner, D. G.; Hinds, K.; Grainger, D. W. Langmuir 1996, 12, 5083-5086.

https://doi.org/10.1021/la960465w

17. Ishida, T.; Choi, N.; Mizutani, W.; Tokumoto, H.; Kojima, I.; Azehara, H.; Hokari, H.; Akiba, U.; Fujihira, M. Langmuir 1999, 15, 6799-6806.

https://doi.org/10.1021/la9810307

18. Bensebaa, F.; Zhou, Y.; Deslandes, Y.; Kruus, E.; Ellis, T. H. Surf. Sci. 1998, 405, L472-L476.

https://doi.org/10.1016/S0039-6028(98)00097-1

19. Imabayashi, S.; lida, M.; Hobara, D.; Feng, Z. Q.; Niki, K.; Kakiuchi, T. J. Electroanal. Chem. 1997, 428, 33-38. https://doi.org/10.1016/S0022-0728(97)00006-5

20. Kakiuchi, T.; Usui, H.; Hobara, D.; Yamamoto, M. Langmuir 2002, 18, 5231-5238.

https://doi.org/10.1021/la011560u

21. This charge value is $37 \%$ greater than the theoretical value, $73 \mu \mathrm{C} / \mathrm{cm}^{2}$, which is expected based on a $(\sqrt{3} \times$ $\sqrt{3}) \mathrm{R} 30^{\circ}$ packing pattern for adsorbed sulfur atoms. This difference is due to the surface roughness of the 
Au substrate and to a discharge current that results from the removal of the adsorbed molecules upon reduction. $^{20}$

22. Molina, L. M.; Hammer, B. Chem. Phys. Lett. 2002, 360, 264-271.

\section{https://doi.org/10.1016/S0009-2614(02)00841-2}

23. Batsanov, S. S. Inorg. Mater. 2001, 37, 871-885.

\section{https://doi.org/10.1023/A:1011625728803}

24. Malgrange, C.; Ricolleau, C.; Schenker, M. Symmetry and Physical Properties of Crystals; Springer: Dordrecht, 2014, Chapter 3.

https://doi.org/10.1007/978-94-017-8993-6

25. Oura, K.; Lifshits, V. G.; Saranin, A. A.; Zotov, A. V.; Katayama, M. Surface Science: An Introduction, Springer: Berlin, 2003, Chapter 2.

https://doi.org/10.1007/978-3-662-05179-5

26. Yurchenko, A. G.; Fedorenko, T. V. Zh. Org. Khim. 1987, 23, 970-976.

27. Fuchs, W.; Kalbacher, H.; Voelter, W., Org. Magn. Reson. 1981, 17, 157-162.

\section{https://doi.org/10.1002/mrc.1270170302}

28. Mutulis, F.; Polis, J.; Raguele, B.; Sekacis, I.; Mishnev, A. F.; Cipens, G. Zh. Org. Khim. 1989, 25, 558-565. https://doi.org/10.1021/jp010127q

29. Excessive fragmentation occurred even with a low electron beam energy of $20 \mathrm{eV}$.

30. Heister, K.; Zharnikov, M.; Grunze, M.; Johansson, L. S. O. J. Phys. Chem. B 2001, 105, 4058-4061.

31. Koch, W.; Holthausen, M. C. A Chemist's Guide to Density Functional Theory; 2nd ed., Wiley-VCH, Weinheim, 2000.

32. Frisch, M. J.; Trucks, G. W.; Schlegel, H. B.; Scuseria, G. E.; Robb, M. A.; Cheeseman, J. R.; Montgomery, J. A., Jr.; Vreven, T.; Kudin, K. N.; Burant, J. C.; Millam, J. M.; Iyengar, S. S.; Tomasi, J.; Barone, V.; Mennucci, B.; Cossi, M.; Scalmani, G.; Rega, N.; Petersson, G. A.; Nakatsuji, H.; Hada, M.; Ehara, M.; Toyota, K.; Fukuda, R.; Hasegawa, J.; Ishida, M.; Nakajima, T.; Honda, Y.; Kitao, O.; Nakai, H.; Klene, M.; Li, X.; Knox, J. E.; Hratchian, H. P.; Cross, J. B.; Bakken, V.; Adamo, C.; Jaramillo, J.; Gomperts, R.; Stratmann, R. E.; Yazyev, O.; Austin, A. J.; Cammi, R.; Pomelli, C.; Ochterski, J. W.; Ayala, P. Y.; Morokuma, K.; Voth, G. A.; Salvador, P.; Dannenberg, J. J.; Zakrzewski, V. G.; Dapprich, S.; Daniels, A. D.; Strain, M. C.; Farkas, O.; Malick, D. K.; Rabuck, A. D.; Raghavachari, K.; Foresman, J. B.; Ortiz, J. V.; Cui, Q.; Baboul, A. G.; Clifford, S.; Cioslowski, J.; Stefanov, B. B.; Liu, G.; Liashenko, A.; Piskorz, P.; Komaromi, I.; Martin, R. L.; Fox, D. J.; Keith, T.; Al-Laham, M. A.; Peng, C. Y.; Nanayakkara, A.; Challacombe, M.; Gill, P. M. W.; Johnson, B.; Chen, W.; Wong, M. W.; Gonzalez, C.; Pople, J. A. Gaussian 03, Revision E.01, Gaussian, Inc., Wallingford CT, 2004. 